\title{
K3 UNTUK PENINGKATAN KESELAMATAN DIRI PERAWAT
}

\author{
Ade Herawati Sahputri \\ adehera92@gmail.com
}

\section{Latar Belakang}

Kesehatan dan keselamatan kerja merupakan salah satu masalah yang sangat penting. Kecelakaan kerja secara langsung maupun tidak langsung dapat menimbulkan kerugian bagi perusahaan antara lain, terlambatnya penyelesaian pekerjaan, penurunan produktivitas, serta biaya penyembuhan bagi karyawan. Kerugian yang ditimbulkan tidak hanya kerugian materi bagi perusahaan namun juga dapat menimbulkan korban jiwa serta penderitaan bagi tenaga kerja yang mengalami kecelakaan

Rumah sakit menjadi salah satu tempat yang wajib menerapkan sistem manajemen keselamatan dan kesehatan kerja (SMK3). Kesehatan dan keselamatan kerja merupakan upaya untuk memberikan jaminan keselamatan dan meningkatkan derajat kesehatan pekerja dengan cara pencegahan Kecelakaan Akibat Kerja (KAK) dan Penyakit Akibat Kerja (PAK) melalui upaya pengendalian bahaya ditempat kerja, promosi kesehatan, pengobatan dan rehabilitasi. Sistem manajemen kesehatan dan keselamatan kerja penting dilaksanakan, mengingat kegiatan rumah sakit berpotensi menimbulkan bahaya fisik, kimia, biologi, ergonomik dan psikososial yang dapat membahayakan kesehatan dan keselamatan baik terhadap pekerja, pasien, pengunjung maupun masyarakat di lingkungan rumah sakit

Pelaksanaan program Kesehatan dan Keselamatan Kerja (K3) yang baik sangat penting untuk menjamin kesehatan dan keselamatan perawat. Penelitian pada tahun 2014 mengungkapkan bahwa untuk meminimalkan Kecelakaan Akibat Kerja (KAK) dan Penyakit Akibat Kerja (PAK) maka pihak rumah sakit harus melakukan monitoring dan evaluasi pada perawat secara berkesinambungan. Pelatihan mengenai Kesehatan dan Keselamatan Kerja (K3) harus diberikan secara berkala dan berkesinambungan bagi perawat untuk meningkatkan kinerja, pengetahuan dan sikap perawat.

Perawat adalah petugas kesehatan yang paling sering kontak langsung dengan pasien baik secara langsung maupun tidak langsung dalam upaya memberikan asuhan keperawatan. Perawat sebagai salah satu karyawan rumah sakit berhak mendapatkan perlindungan dari gangguan kesehatan ataupun kecelakaan kerja, baik sebagai dampak proses kegiatan 
pemberian pelayanan maupun karena kondisi sarana dan prasarana yang ada di rumah sakit. Pelaksanaan program-program Kesehatan dan Keselamatan Kerja (K3RS) penting untuk mencegah kecelakaan dan penyakit akibat kerja pada perawat.

\section{Metode}

Metode yang digunakan dalam kajian ini adalah metode literature review yaitu metode dengan cara membaca dari berbagai sumber seperti jurnal online, skripsi, dan e-book serta membandingkan isi dari berbagai sumber yang dibaca dan menyimpulkan dalam hasil kajian yang didapatkan pada jurnal, skripsi, e-book tentang ruang lingkup keselamatan dan kesehatan kerja dalam keperawatan.

\section{Hasil}

Pelaksanaan Keselamatan dan Kesehatan Kerja (K3) adalah salah satu bentuk upaya menciptakan tempat kerja yang aman, sehat, bebas dari pencemaran lingkungan, sehingga dapat mengurangi dan atau bebas dari kecelakaan kerja dan penyakit akibat kerja dan dapat berdampak meningkatkan efisiensi dan produktivitas kerja. Kecelakaan kerja tidak saja menimbulkan korban jiwa maupun kerugian materi bagi pekerja dan pengusaha, tetapi juga dapat mengganggu proses produksi secara menyeluruh, merusak lingkungan dan dapat berdampak terhadap masyarakat luas

Perawat dapat terpapar berbagai macam risiko cidera dan penyakit saat bekerja. Petugas kesehatan berisiko lebih tinggi mengalami kecelakaan akibat kerja dan penyakit akibat kerja dibanding pekerja industri lain (Kepmenkes No. 1087, 2010). Penyakit akibat kerja dan kecelakaan akibat kerja pada perawat selain disebabkan oleh faktor lingkungan yang tidak aman (unsafe condition), juga dapat disebabkan oleh perilaku yang tidak aman (unsafe act). Sumakmur (2009) dalam Ayu (2012) menyatakan $85 \%$ sebab terjadinya penyakit akibat kerja dan kecelakaan akibat kerja bersumber pada faktor manusia. Risiko bahaya di rumah sakit mencakup bahaya biologik, fisik, kimia, ergonomik, dan psikososial (Kepmenkes No. 1087, 2010)

Fasilitas pelayanan kesehatan harus memperhatikan keselamatan kerja dari para pekerjanya agar dapat menghasilkan mutu pelayanan yang optimal. Perusahaan tempat bekerja harus memperhatikan faktor utama penentu keselamatan kerja yaitu : a) beban kerja, b) Beban kerja tambahan akibat dari lingkungan kerja . 
Beban kerja adalah sejumlah proses atau kegiatan yang harus diselesaikan oleh seorang pekerja dalam jangka waktu tertentu. Beban kerja adalah sesuatu yang dirasakan berada di luar kemampuan pekerja untuk melakukan pekerjaannya. Beban kerja dapat berupa beban fisik, mental, ataupun beban sosial sesuai jenis pekerjaannya. Beban kerja tambahan adalah beban yang ditimbulkan akibat faktor lingkungan dalam suatu pekerjaan yang dapat berakibat atau mempengaruhi kondisi jasmani dan rohani. Lingkungan pekerja yaitu lingkungan di tempat kerja dan lingkungan pekerja sebagai individu atau lingkungan di luar tempat kerja. Beban kerja tambahan dikelompokkan menjadi lima faktor, yaitu: fisik, kimia, biologi, faal ergonomic, dan psikososial.

\section{Pembahasan}

Fasilitas pelayanan kesehatan harus menjamin keamanan, kenyamanan dan kesehatan para perawat. Perusahaan harus menciptakan lingkungan tempat kerja yang sehat. Adapun syarat lingkungan kerja yang sehat adalah sebagai berikut: suhu ruangan yang nyaman, penerangan atau pencahayaan yang cukup. bebas dari debu, sikap badan yang baik, alat-alat kerja yang sesuai dengan ukuran tubuh, harus ergonomis.

Peran kesehatan dan keselamatan kerja dalam ilmu kesehatan kerja berkontribusi dalam upaya perlindungan kesehatan para perawat dengan upaya promosi kesehatan, pemantauan, dan survailan kesehatan serta upaya peningkatan daya tahan tubuh dan kebugaran pekerja. Sementara peran keselamatan adalah menciptakan sistem kerja yang aman atau yang mempunyai potensi risiko yang rendah terhadap terjadinya kecelakaan dan menjaga aset perusahaan dari kemungkinan loss.

Kecelakaan kerja disebabkan oleh beberapa faktor menurut anizar (2009) secara umum penyebab kecelakaan ada dua, yaitu unsafe action dapat disebabkan oleh berbagai hal berikut, ketidakseimbangan fisik tenaga kerja, seperti: posisi tubuh yang menyebabkan mudah lelah, cacat fisik, cacat sementara, kepekaan panca indra terhadap sesuatu. Kurang pendidikan, kurang pengalaman, salah pengertian terhadap suatu perintah, kurang terampil, salah mengartikan sop (standard operasional procedur) sehingga mengakibatkan kesalahan pemakaian alat kerja atau penggunaan alat itu sendiri. Keselamatan dan kesehatan kerja merupakan hal yang penting bagi perusahaan, karena dampak kecelakaan dan penyakit kerja tidak hanya merugikan karyawan, tetapi juga perusahaan baik secara langsung maupun tidak langsung (Kusuma, 2001). Sasaran utama dari K3 ditujukan terhadap perawat, dengan 
melakukan segala daya upaya berupa pencegahan, pemeliharaan dan peningkatan kesehatan tenaga kerja, agar terhindar dari risiko buruk di dalam melakukan pekerjaan.

Indikator Keselamatan dan Kesehatan Kerja (K3) Menurut (Dessler:1997), indicator kesehatan karyawan terdiri dari : 1.) Keadaan dan Kondisi Karyawan. Keadaan dan kondisi karyawan adalah keadaan yang dialami oleh karyawan pada saat bekerja yang mendukung aktifitas dalam bekerja. 2). Lingkungan kerja. Lingkungan kerja adalah lingkungan yang lebih luas dari tempat kerja yang mendukung aktifitas karyawan dalam bekerja. 3.) Perlindungan karyawan.Perlindungan karyawan merupakan fasilitas yang diberikan untuk menunjang kesejahteraan karyawan. Menurut (Suma'ar:1986) adapun indicator-indikator keselamatan kerja meliputi : 4.) Tempat kerja adalah merupakan lokasi dimana para karyawan melaksanakan aktifitas kerjanya. 5.) Mesin dan peralatan adalah bagian dari kegiatan operasional dalam proses produksi yang biasanya berupa alat-alat berat dan ringan.

Beberapa factor-faktor yang dapat dijadikan sebagai alat pengukur kepuasan kerja karyawan menurut Siagian (2008:296), yaitu : a) Prestasi Kerja perawat . Yaitu bahwa seseorang merasa puas dalam pekerjaannya karena yang bersangkutan menyadari bahwa apa yang dicapainya sudah maksimal. Dalam situasi demikian dia berusaha berprestasi sebaik mungkin. b.) Tingkat Kemangkiran perawat. Yaitu karyawan yang tinggi tingkat kepuasan kerjanya akan rendah tingkat kemangkirannya. Sebaiknya, karyawan yang rendah tingkat kepuasan kerjanya akan cendrung tinggi tingkat kemangkirannya. c.) Keinginan pindah perawat . Yaitu salah satu factor penyebab timbulnya keinginan pindah kerja adalah ketidakpuasan pada tempat kerja sekarang. Sebabsebab ketidakpuasan itu dapat beranekaragam seperti penghasilan rendah atau dirasakan kurang memadai, kondisi kerja yang kurang memuaskan, hubungan yang tidak serasi, baik dengan atasan maupun dengan para reka sekerja, dan factor lainnya. Keinginan pindah dapat berpengaruh terhadap kepuasan kerja, jika kepuasan kerja tinggi maka keinginan pindah rendah, dan begitu juga sebaliknya. d. Lama bekerja Perawat . Yaitu kecendrungan yang sering terlihat ialah bahwa semakin lanjut usia karyawan, tingkat kepuasan kerjanya pun biasanya semakin tinggi, alasan sering dikemukakan menjelaskan fenomena ini antara lain : gaya hidup yang sudah mapan, sumber penghasilan yang relative terjamin, adanya ikatan batin dan tali persahabatan antara yang bersangkutan dengan rekanrekannya dalam organisasi.

Penerapan manajemen Kesehatan dan Keselamatan Kerja (K3) ditinjau dari faktor internal diantaranya persepsi. Persepsi merupakan suatu proses pencarian informasi yang dilakukan oleh perawat sebelum melakukan suatu tindakan. Persepsi perawat tentang K3 menunjukkan 
bagaimana perawat mampu mencari tahu tentang pentingnya $\mathrm{K} 3$ baik melalui brosur, leaflet, SOP yang disediakan di ruangan maupun media informasi lainnya. Perawat juga dituntut untuk faham bagaimana cara pencegahan kecelakaan serta penanganan yang dapat dilakukan apabila kecelakaan terjadi. Sikap juga mempengaruhi perilaku perawat ditinjau dari segi faktor internal (Notoadmodjo, 2010). Seorang perawat dalam melaksanakan manajemen K3 harus memiliki sikap yang sesuai dengan nilai-nilai kesehatan dimana seluruh nilai positif yang ada dalam dirinya menjadi pendorong perilaku sehat dan menjadi upaya dalam meningkatkan kesehatan dan keselamatan selama bekerja. Selain itu, Notoadmodjo (2010) menambahkan bahwa ada berbagai cara yang dapat dilakukan untuk meningkatkan persepsi, pengetahuan dan sikap perawat dalam menjaga kesehatan dan keselamatan selama bekerja, diantaranya dengan memberikan promosi kesehatan dan pelatihan tentang K3 sehingga hal ini diharapkan mampu merubah perilaku perawat menjadi lebih baik.

Faktor eksternal juga sangat mempengaruhi perilaku perawat dalam penerapan manajemen K3 di rumah sakit. diantaranya pengalaman. Pengalaman perawat dapat dilihat dari berbagai aspek. Salah satunya adalah masa kerja. Semakin lama masa kerja perawat maka pengalaman yang dimiliki juga semakin meningkat sehingga perilakunya dalam menjaga keselamatan dirinya juga menjadi lebih baik. Selain itu pengalaman juga dapat diperoleh dari berbagai sosialisasi maupun pelatihan tentang K3 yang dilakukan oleh pihak rumah sakit. Faktor selanjutnya yang ikut berperan dalam perubahan perilaku perawat yaitu tersedianya fasilitas yang mendukung sesuai dengan standar yang telah ditentukan. Hal ini sejalan dengan penelitian Tukatman, Sulistiawati, Purwaningsih dan Nursalam (2015) yang menyebutkan bahwa faktor enabling (fasilitas keamanan dan keselamatan, hukum/aturan) pada perawat berpengaruh terhadap K3 pada perawat dalam penanganan pasien. Nilai yang paling tinggi pada faktor enabling berada pada komponen hukum/aturan, artinya secara umum perilaku seseorang dipengaruhi oleh aturan yang ada di lingkungannya.

Beban kerja tambahan dikelompokkan menjadi lima faktor, yaitu: 1) Faktor fisik. Beban kerja tambahan dapat disebabkan karena faktor fisik, misalnya penerangan atau pencahayaan yang tidak cukup, suhu udara yang panas, kelembaban yang tinggi atau rendah, suara yang bising, baubauan dan sebagainya.Bahaya atau masalah kesehatan yang bisa muncul dari faktor fisik ini, yaitu: tuli permanen akibat kebisingan, heat stress, Raynaud's syndrome, terpeleset, leukemi akibat radiasi X-ray, radioterapi dan sebagainya. 2.) Faktor kimia Beban kerja tambahan dapat disebabkan karena faktor kimia. Faktor kimia yaitu semua bahan kimia yang dipakai dalam lingkungan kerja, misalnya gas (sianida, gas asam sulfida, CO), uap (uap logam), 
debu (asbes, berilium, biji timah putih) dan larutan (asam kuat dan basa kuat). Faktor kimia ini mempengaruhi fungsi tubuh sehingga menurunkan daya kerja. Bahaya faktor kimia merupakan faktor yang sering terjadi di fasilitas pelayanan kesehatan sehingga menyebabkan gangguan keselamatan dan kesehatan kerja. 3) Faktor biologi. Faktor biologi umumnya menyebabkan penurunan konsentrasi kerja dan kondisi kesehatan pekerja sehingga sakit. Faktor biologi dapat disebabkan oleh: bakteri, virus, jamur, parasite. Penyakit yang disebabkan oleh parasit, misalnya Ankilostomiasis, Tripanosomiasis. 4.) Faktor Faal ergonomic. Faktor faal ergonomi merupakan faktor yang disebabkan karena perlengkapan kerja yang tidak sesuai dengan ukuran badan atau anggota tubuh sehingga menyebabkan kelelahan kerja. Perlengkapan kerja, misalnya meja dan kursi yang terlalu tinggi atau pendek dan sebagainya. 5.) Faktor Psikologi Faktor psikologi dapat disebabkan karena suasana kerja yang tidak harmonis misalnya pekerjaan monoton, gaji yang kurang, jalinan atasan bawahan yang kurang baik dan sebagainya. Hal itu dapat menyebabkan stress kerja dengan tanda-tanda psikosomatis berbentuk mual, muntah, sakit kepala, nyeri ulu hati, jantung berdebar-debar dan sebagainya sehingga menimbulkan kebosanan, tidak betah dan akhirnya produktifitas kerja menurun.

\section{Penutup}

Dalam keselamatan dan kesehatan kerja perawat ada beberapa faktor yang perlu diperhatikan yaitu : faktor fisik, kimiawi, biologi, faal ergonomic, dan psikososial. Masing-masing faktor memiliki bahaya yang dapat mengancam keselamatan perawat. Oleh karena itu perawat harus melakukan manajemen kessssehatan dan keselamatan kerja (K3). Dalam hal ini ada 2 faktor yaitu internal dan eksternal. Faktor internal terdiri atas persepsi dan sikap. Sedangkan faktor eksternal terdiri dari pengalaman dan faktor enabling (fasilitas keamanan dan keselamatan, hukum/aturan).

\section{Daftar Pustaka}

ASMIRAJANTI, MIRA. 2019. MODUL KESELAMATAN PASIEN DAN KESELAMATAN KESEHATAN KERJA DALAM KEPERAWATAN. Universitas Esa Unggul.

Mahdarsari, M \& H.H, H.P . 2016. PENINGKATAN KESELAMATAN DIRI PERAWAT MELALUI OPTIMALISASI FUNGSI MANAJEMEN. Jurnal Keperawatan Indonesia. 19 (3), hal. $176-183$

Nazirah, R \& Yuswardi. 2017. PERILAKU PERAWAT DALAM PENERAPAN MANAJEMEN KESEHATAN DAN KESELAMATAN KERJA (K3) DI ACEH. Idea Nursing Journal. 8 (3). 
Nurhidayanti, Deni. 2017. PENGARUH PELAKSANAAN KESELAMATAN DAN KESEHATAN KERJA (K3) TERHADAP KEPUASAN KERJA PERAWAT (Studi Kasus Rumah Sakit Umum Daerah (RSUD) Arifin Achmad Pekanbaru). JOM FISIP. 4 (1), hal $1-10$.

Pitoyo, J dkk. 2017. KEPATUHAN PERAWAT MENERAPKAN PEDOMAN KESELAMATAN KERJA DAN KEJADIAN CEDERA PADA PERAWAT INSTRUMEN DI INSTALASI BEDAH SENTRAL. JURNAL PENDIDIKAN KESEHATAN. 6 (2), hal. 65-70.

P, S. M. dkk. 2015. KEJADIAN KECELAKAAN KERJA PERAWAT BERDASARKAN TINDAKAN TIDAK AMAN. Jurnal Care . 3 (2), hal. 9 - 17

Putri. O. Z. \& dkk. 2017. ANALISIS RISIKO KESELAMATAN DAN KESEHATAN KERJA PADA PETUGAS KESEHATAN INSTALASI GAWAT DARURAT RUMAH SAKIT AKADEMIK UGM. JURNAL KESEHATAN. 10 (1), hal. 1 - 12

Putri, S. dkk. 2018. PELAKSANAAN KESELAMATAN DAN KESEHATAN KERJA TERHADAP KEJADIAN KECELAKAAN KERJA PERAWAT RUMAH SAKIT. Jurnal Endurance . 3(2), hal. 271-277

RAHMAWATI, RULI. 2017. “ GAMBARAN PENERAPAN PROGRAM KESEHATAN DAN KESELAMATAN KERJA RUMAH SAKIT ( K3RS ) PADA PERAWAT DI RSUD TUGUREJO SEMARANG “. Proposal Skripsi. DEPARTEMEN ILMU KEPERAWATAN. FAKULTAS KEDOKTERAN. UNIVERSITAS DIPONEGORO : SEMARANG.

Rejeki, Sri. 2016. KESEHATAN dan KESELAMATAN KERJA. Kementerian Kesehatan Republik Indonesia : Jakarta

Salmawati, L dkk. 2015. HUBUNGAN PENERAPAN SISTEM MANAJEMEN KESELAMATAN DAN KESEHATAN KERJA DENGAN MOTIVASI KERJA DAN STRES KERJA PADA PERAWAT DI RUMAH SAKIT UMUM ANUTAPURA PALU. JURNAL MANAJEMEN PELAYANAN KESEHATAN. 18 (1), hal. 4 - 6.

Simamora, R. H. (2018). Buku ajar keselamatan pasien melalui timbang terima pasien berbasis komunikasi efektif: SBAR. Medan: USUpress.

Simamora, R. H. (2019). Buku ajar pelaksanaan identifikasi pasien. Uwais Inspirasi Indonesia 
